\title{
Notes on vultures (Cathartidae) in Paraguay with a supporting bibliography Paul Smith $^{*}$
}

FAUNA Paraguay, Encarnación, Dpto. Itapúa, Paraguay www.faunaparaguay.com.

*Corresponding author: faunaparaguay@gmail.com

\begin{abstract}
Paraguay is often overlooked by ornithological researchers as much of its literature is obscure, hard to find or published locally. This is equally true of Cathartid vultures. In an effort to bring this information to a wider audience, we provide a summary of the published Paraguayan literature for each of the four species of vultures that occur in the country, including a history of vulture studies, folklore, a local synonymy and an attempt at a complete bibliography.
\end{abstract}

\section{Introduction}

Despite one of the longest histories of ornithological research in South America (Azara 1802, 1805a,b), Paraguay retains a reputation for being "unexplored" and "under-studied" (Freile et al. 2014). Whilst in some respects this is a fair assessment, in others it is simply a case of published data being difficult to find or published in obscure, locally-produced serials that now exist only as moth-eaten copies in an increasingly small number of national libraries.

In an effort to consolidate what is known about Cathartidae in Paraguay, I here provide a brief summary of some of the more interesting and country-specific information on vultures that is available. The aim is not to compile all of this information into a single publication, but to provide a gateway to it, so that such information is more visible and perhaps more accessible for consideration by a wider audience. Finally, an attempt at a useful bibliography of Paraguayan references that cite these species is provided, which I hope will be of use to researchers.

\section{History of studies on vultures in Paraguay}

The earliest published mention of vultures in
Paraguay appears to be from the mid- $18^{\text {th }}$ Century when Sánchez Labrador (1910) referred to "cuervos de cabeza encarnada" (vultures with bald heads) which the Guaraní referred to as "Napirai". He noted that they lacked feathers on the head and that the colouration came from the wrinkled skin "like the crest of chickens, but not raised." The same author provides considerably more detail in a work dated 1767 (in Castex 1968), giving descriptions of behaviour, diet, breeding and appearance, including possibly one of the first references to vultures killing injured or wounded animals, as well as the obligatory nod to hygiene services. He apparently described all four species under three names, Rey de los urubus (juvenile King Vulture, but clearly also including Black Vulture), Otro rey (Lesser Yellow-headed Vulture), Urubu pita (Turkey Vulture) and repeatedly attributed to them a disgusting smell.

Azara (1802) in his groundbreaking work on Paraguayan birds described just three species of vulture: No.1 Iriburubichá (King Vulture); No. 2 Iribú (Black Vulture) and No. 3 Acabiráy (Turkey Vulture) (Sonnini in Azara 1809, Hartlaub 1847). He noted the impropriety of the name cuervo and highlighted their role in disease prevention, maintenance of hygiene and their "peaceful 
nature", stating these as the reasons for placing them at the beginning of his three-volume work. On the other hand, he also noted that all species smell bad, lack a voice and are clumsy on the ground. Azara's descriptions are extremely detailed and though he did not give scientific names for the species, they are easily recognizable and largely accurate. He also took the liberty of correcting Buffon in noting the differences between the New World and Old World vultures. The published addition of the fourth species of vulture (Lesser Yellow-headed Vulture) was by Grant (1911) (Sánchez Labrador's manuscript would remain unpublished until half a century later), who described a Cathartes aura specimen as having a yellow head. The nomenclatural error was eventually corrected in Bertoni (1914a), though he treated the species with a query.

In a text on "useful birds", Bertoni (1900) barely expanded on Azara's (1802) descriptions, showing how little progress had been made in the preceding century. He again repeated the mantra of their inoffensive nature and strong unpleasant odour, adding that the species have excellent senses of sight and smell, and are not seen in the forested Alto Paraná region (the historic extent of the Atlantic Forest ecoregion in eastern Paraguay) until there is a corpse, at which point they appear in flocks without "anybody knowing where they came from". Bertoni $(1900,1901)$ included all species in the family Vulturidae in keeping with $19^{\text {th }}$ Century usage (Sharpe 1874), but the use of Cathartidae has been promoted since at least Wetmore (1926). The validity of the current usage of Cathartidae in fact requires serious investigation (Brodkorb 1964, Blake 1977, Bock 1994, Olson 1995).

An interesting early note dealing specifically with vultures (Bertoni 1914b) discusses a proposal made in the Brazilian publication Revista Chácaras e Quintaes to destroy them as vectors of Anthrax (Bacillus anthracis) based on a bizarre experiment in which a Guinea pig (Cavia porcellus) was injected with the faeces of a vulture that had consumed anthrax-infected meat and later confirmed to be inoculated with the bacteria. The argument being made was that the excrement of vultures was thus a likely vector of the disease, and they should be eliminated without mercy. Bertoni (1914b) argued against this theory, noting that the vultures perform a vital role as natural waste disposal units and are thus essential for human hygiene. Both sides of the discussion greatly simplified the mechanisms of disease transmission in ecological systems.

I am unaware of any detailed ecological studies on these species based primarily on observations taken from Paraguay that have taken place since then. Instead, most of the limited ecological data generated has been within the bounds of wider generalist studies, or the product of opportunistic observation of either density (Hayes \& Granizo Tamayo 1992) or reproductive behaviour (Dalgleish 1889, de la Peña 2010).

\section{Vultures in popular Paraguayan culture}

Cathartid vultures are a common and conspicuous component of the Paraguayan avifauna. They are collectively known as "cuervos" in Paraguayan Spanish (literally translated as "crows" although there are no true crows in Paraguay), or as "yryvu" in the Guaraní language (or "guopoba" of the Mbyá). Other Spanish vernacular names used in other Latin American countries (e.g. jota, zopilote etc.) are neither used nor widely understood, though Bertoni (1914b) proposed the use of the Old World Spanish word for vultures buitre to avoid confusion with corvids.

The origin of the name yryvu (alternatively written iribu, urubu etc.) is disputed. Pereyra (1945) suggests that it is derived from a combination of uru (chicken) and irebu (stink), thus meaning something like "stinking chicken". However, other authors have suggested alternative meanings such as "black bird" (Sánchez Labrador 
in Castex 1968).

With 19 different indigenous peoples recognized as inhabiting Paraguay it is impossible to give adequate coverage here to their varied cultural beliefs and usages in relation to vultures. An incomplete attempt is made to address some of these at the specific level in the "cultural value" sections of the species accounts, but I will restrict discussion here to a brief, general, mention of some of the more well-known cultural practices and beliefs that apply more broadly to all members of the family, whilst urging interested readers to seek out the original references for the necessary detail.

In some foundational theories the early Guaraní took fire from the vultures and carrion-eating birds (Melia 2006), and some cultures see them as the reincarnation of important ancestors (Sánchez et al. 2019). According to Schmeda-Hirschmann (1993), during his initiation, the last living Naijna (shaman) of the Ayoreo Totobiegoosode climbed a Quebracho tree (either Schinopsis or Aspidosperma species) and was spoken to by several bird spirits, among them at least two species of vulture, 'Chuguperejna' (King Vulture) and 'Eapotoe' (Turkey Vulture). The size and abundance of vultures means that their feathers can be obtained relatively easily and they are thus utilized for a number of different purposes by indigenous groups, notably for adorning decorative clothing or as flights for arrows (Dobrizhoffer 1784, Sánchez Labrador 1910, Madroño-Nieto 2011). For further information on the role of birds in the culture of specific indigenous groups I direct readers to the following references: Ache (Madroño-Nieto 2011), Ayoreo Totobiegosode (Sánchez et al. 2019), Mbyá (Cadogan 1959-1992).

Sánchez Labrador (in Castex 1968) discussed some "medicinal virtues" of vultures in general which he attributed to "the Spanish". He claimed that the ashes of burnt feathers impede hair growth and cure wounds, that eating the flesh protects against syphilis, and eating the flesh in addition to holding the roasted skin against a wound, will also help to heal it. Rather more outlandish is the claim that drinking a dram of their dissolved dry dung is an effective way to combat melancholy.

Misconceptions on the behaviour of vultures continue to this today. The charge of attacking livestock is commonly heard (Castex 1968, Sánchez 2016), but while this is not entirely inaccurate (Bent 1937, Lovell 1947, Lowney 1999, Melo et al. 2018), such predation events are rare and typically on young or infirm animals (Melo et al. 2018, Lambertucci et al. 2021). Predation events, with very occasional exceptions (Mueller \& Berger 1967, Glading \& Glading 1970), involve Black Vultures, though such specific distinctions are not rarely made by their accusers. With the exception of Sánchez Labrador (in Castex 1968) I am unaware of any documented reports of vulture predation happening in Paraguay however, though it would seem certain to occur at least occasionally. Dobrizhoffer (1784) in fact spoke of the utility of these birds in treating the infected wounds of livestock, stating that they may be known as "horse's physicians" as they pick at the worms and dried blood of wounds, though he also noted that they may also enlarge wounds in the process.

Superstition surrounds these birds, based principally on their unattractive appearance and rather more loosely on their biology. The "sinisterlooking" Black Vulture, for example is often considered a bird of "mal agüero" (bad omen), with the presence around a homestead interpreted as a prediction of impending death. Indeed, this idea that these birds cannot be trusted is reflected in popular language, where politicians suspected of corruption may be referred to as "parlamentarios yryvu" (vulture parliamentarians) for their alleged habit of scavenging a living whilst providing nothing in return (Scavone 2014). 


\section{Methods}

A thorough view of the Paraguayan literature and specimen record was performed during the author's preparation of a review and status of the birds of Paraguay (Smith \& Clay in press). Grey literature (government reports, rapid ecological assessments and university theses etc.) was excluded. Five species of vulture have been traditionally stated to occur in Paraguay (Hayes 1995, Guyra Paraguay 2004, 2005), but this is reduced to four here with one species considered of possible occurrence and one species treated as erroneously cited (Smith \& Clay in press). Each species is presented separately below. Species accounts take the following format:

Common English name Scientific name (Author, Date).

Original name Author, date: page number Synonym (publications): The synonyms listed are those cited in the Paraguayan literature and the publications in parentheses that follow are Paraguayan focused publications in which the name is used. It is not intended to be a complete synonymic listing for the entire species range. After each publication a one-word qualifier summarizing the type of data included in each publication is provided (see below for definitions of these).

Local names: These are local names in use in Paraguay. This is not a complete listing of local names from throughout the species range. A rough translation is provided where this is available. The following abbreviations are used for the languages: SPA for Castillian Spanish; GUA for Guaraní, the official language of the country; ACHE for Aché, an indigenous group from the north-eastern Oriental region of Paraguay (Chachugi 2013); TOTO for Ayoreo Totobiegosode, an indigenous group of the Chaco region west of the Paraguay river (Sánchez et al. 2019); MBYA for Mbyá, an indigenous group of the southern and eastern Oriental region of Paraguay (Castex 1968).

Distribution: A brief discussion of the known distribution and habitat associations in Paraguay.

Specimens: Location of known Paraguayan museum specimens of the species. The following acronyms are used: CM for Carnegie Museum; CUMV for Cornell University Museum of Vertebrates; DMNS for Denver Museum of Natural Science; FMNH for Field Museum of Natural History; MHNG for Natural History Museum of Geneva; MNHNP for Museo Nacional de Historia Natural del Paraguay, San Lorenzo, Paraguay; MVZ for Museum of Vertebrate Zoology; NHM for The Natural History Museum, London; NRM for Swedish Museum of Natural History, Stockholm; RBINS for the Royal Belgian Institute of Natural Sciences; SMF for Senckenberg Forschungsinstitut und Naturmuseum, Frankfurt; UMMZ for University of Michigan Museum of Zoology; USNM for National Museum of Natural History, Smithsonian Institute; WFVZ for Western Foundation of Vertebrate Zoology; YPM for Yale Peabody Museum; ZFMK for Zoologisches Forschungsmuseum Alexander Koenig, Bonn; ZSM for Zoologische Staatssammlung München;

The following terms are used in the bibliography section to describe the main topics of each reference: abundance, behaviour, biogeography, breeding, checklist, density, distribution, ecology, ethnology, flock size, guide, habitat, identification, mass, moult, parasitology and specimens. 


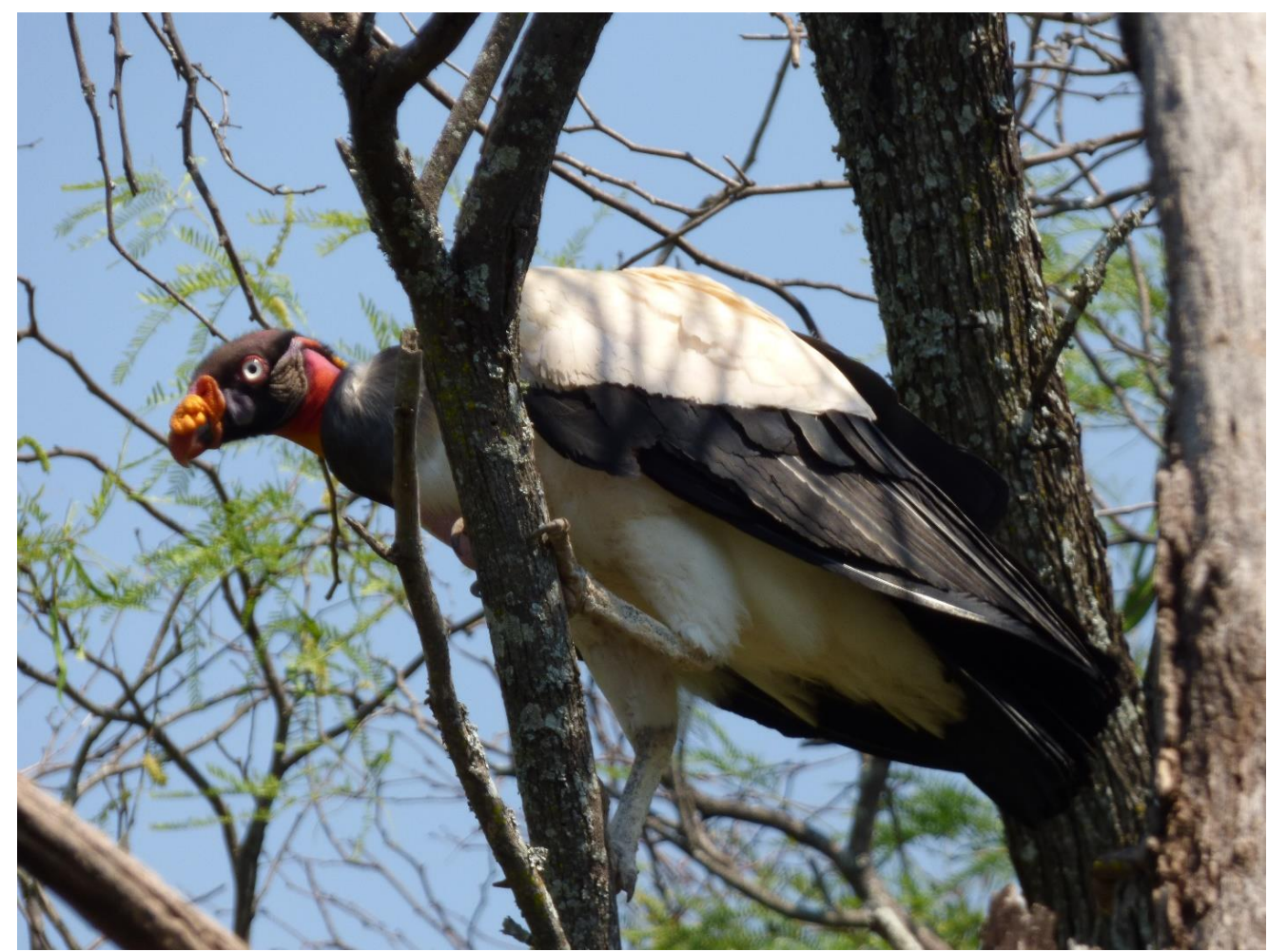

Figure 1: King Vulture Sarcoramphus papa at Teniente Enciso National Park, Boquerón department, 11 September 2017 (Paul Smith).

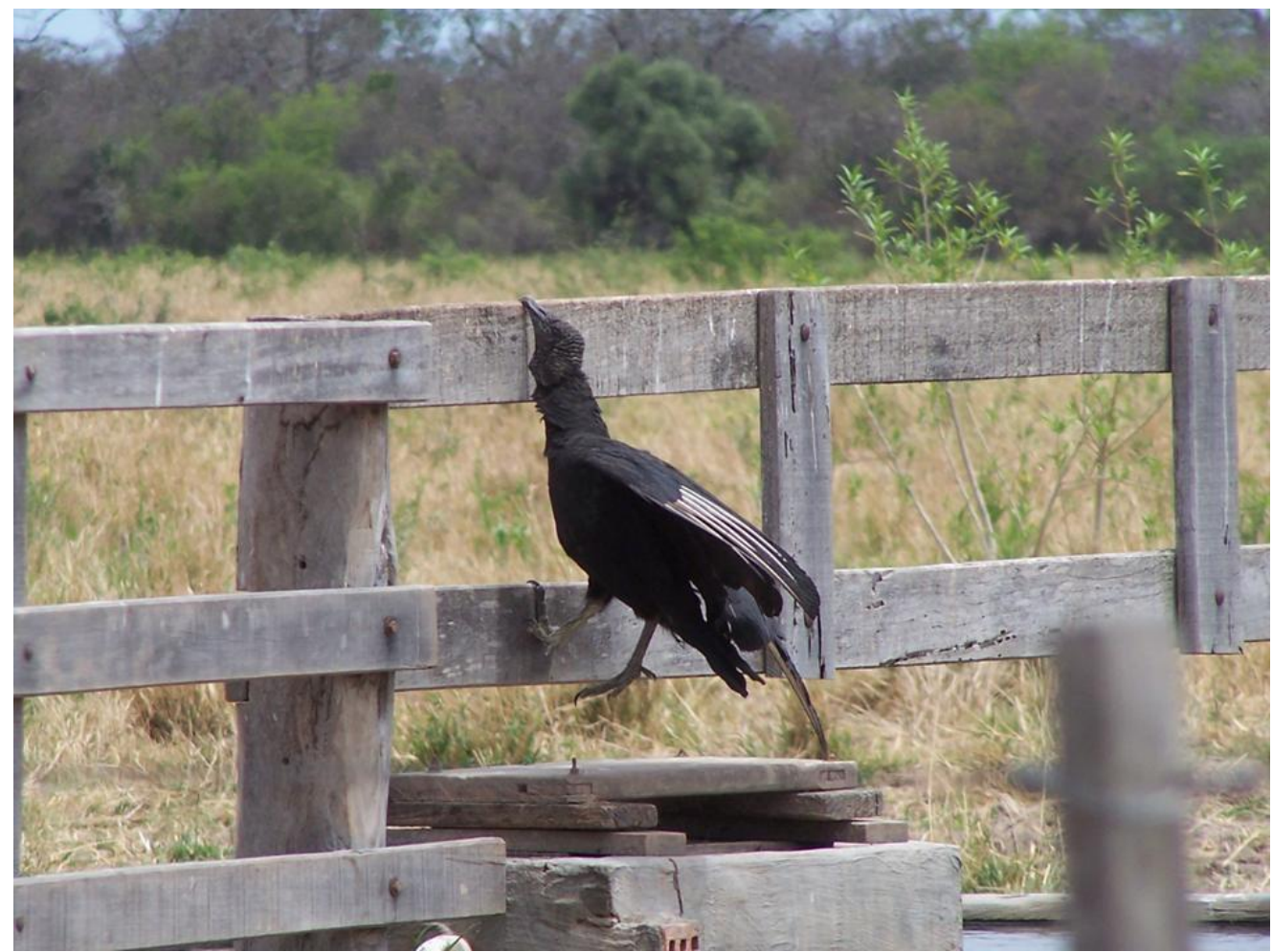

Figure 2: An injured Black Vulture Coragyps atratus foetens climbing a fence at Laguna Bombacha, Presidente Hayes department, October 2007 (Paul Smith). 


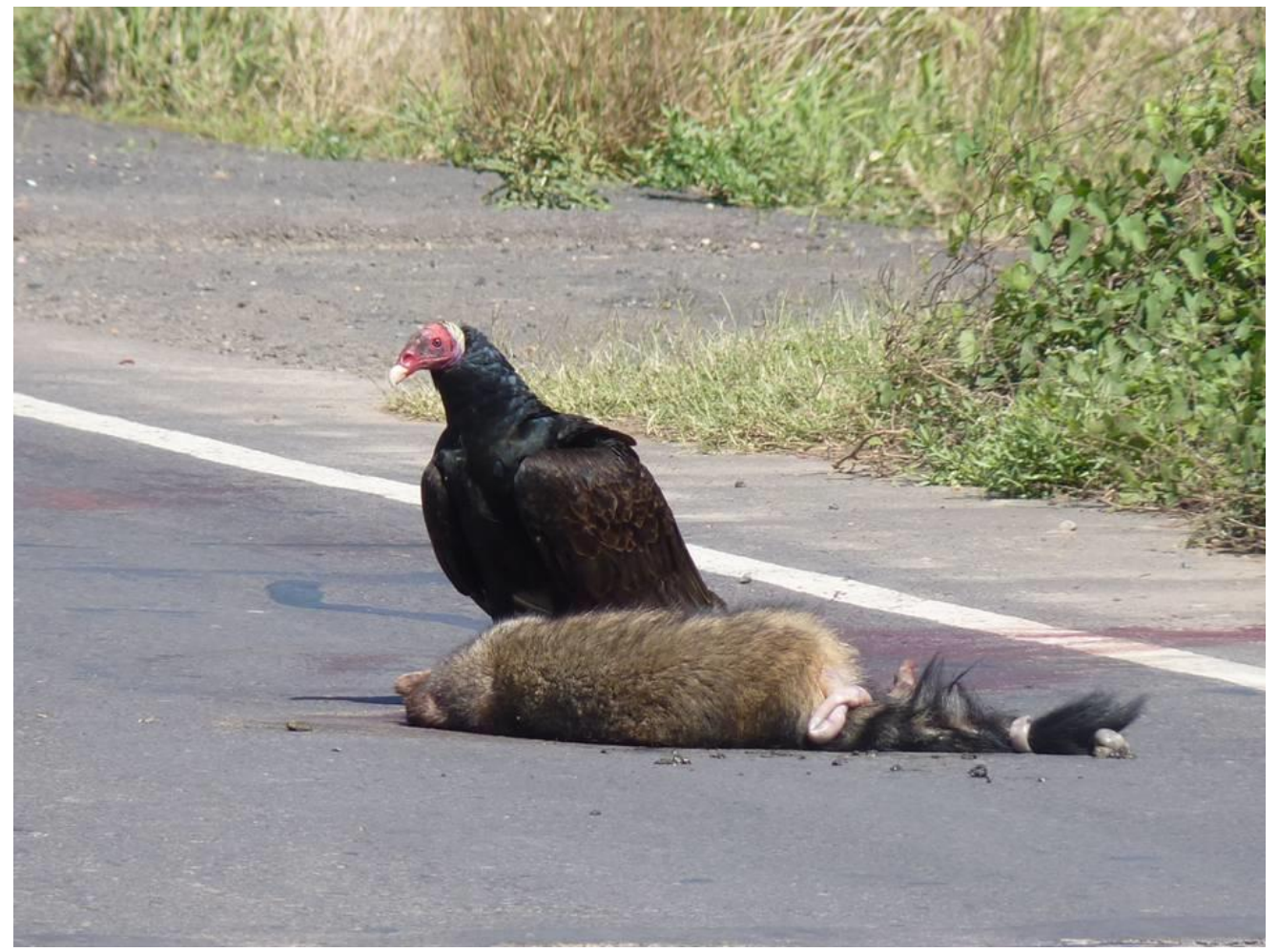

Figure 3: Turkey Vulture Cathartes aura ruficollis feeding on roadkill Crab-eating Raccoon Procyon cancrivorus at km 290 Transchaco Road, Presidente Hayes department, 23 ${ }^{\text {rd }}$ August 2011 (Paul Smith).

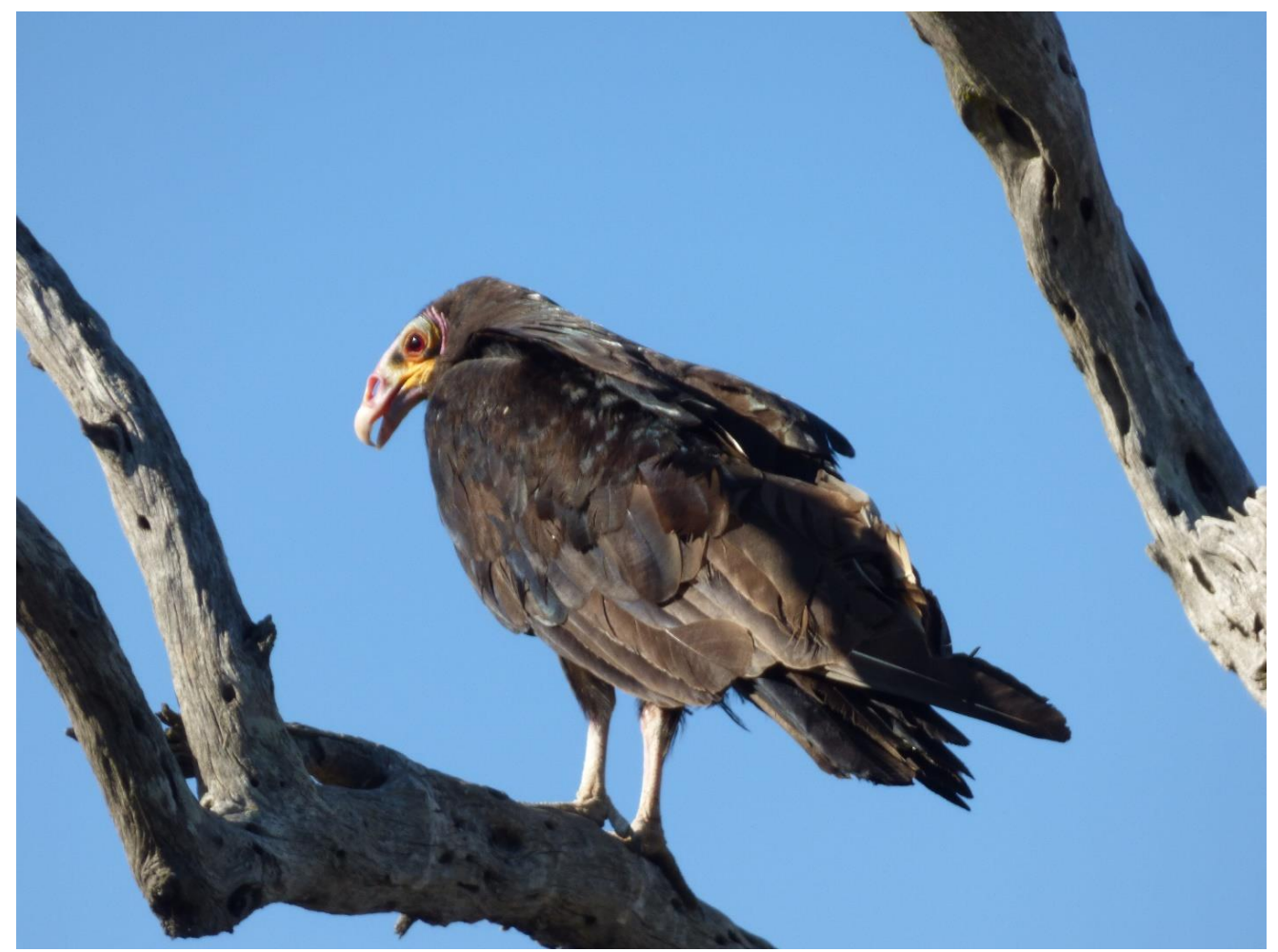

Figure 4: Lesser Yellow-headed Vulture Cathartes burrovianus urubutinga at Laguna Capitán, Presidente Hayes department, $5^{\text {th }}$ August 2019 (Paul Smith). 


\section{Species accounts}

King Vulture Sarcoramphus papa (Linnaeus, 1758) (Figure 1).

[Vultur] Papa Linnaeus, 1758: p.86.

Sarcorhamphus papa Hartlaub 1847 (checklist); Bertoni 1939 (checklist, distribution); Masi Pallarés 2011 (ecology).

Gyparchus papa Berlepsch 1887 (checklist); Bertoni 1900 (ecology, reproduction); Bertoni 1901 (checklist).

Gypagus papa Ihering 1904 (checklist); Bertoni 1914a (checklist, distribution)S.[arcoramphus] papa Hayes \& Granizo Tamayo 1992 (density). Cathartes papa Schmeda-Hirschmann 1993 (ethnology).

Sarcoramphus papa Laubmann 1939 (checklist); Podtiaguin 1941 (checklist); Podtiaguin 1944 (distribution); Pereyra 1945 (checklist); Willim 1947 (distribution); Schade \& Masi Pallarés 1967 (abundance, description); Short 1975 (distribution, habitat); Contreras 1989 (abundance, distribution); Contreras et al. 1990 (checklist); Hayes et al. 1991 (abundance, checklist); Neris \& Colman 1991 (abundance, distribution); Brooks et al. 1993 (abundance, behaviour, conservation, distribution, moult); Hayes 1995 (abundance, biogeography, distribution); Hayes \& Scharf 1995a (abundance, distribution); Perez Villamayor \& Colmán 1995a (distribution); Lowen et al. 1996 (conservation, distribution); Madroño-Nieto et al. 1997a (distribution); Madroño-Nieto et al. 1997b (distribution, habitat); Robbins et al. 1999 (abundance, status, habitat); Mazar Barnett \& Madroño-Nieto 2003 (abundance, guide, identification); Zyskowski et al. 2003 (distribution); Guyra Paraguay 2004 (abundance, distribution, habitat, status); Guyra Paraguay 2005 (abundance, distribution, habitat, status); Smith et al. 2005b (distribution, status); Elsam 2006 (guide, identification);
Narosky \& Yzurieta 2006 (guide, identification); Smith et al. 2006a (distribution); Smith et al. 2006b (distribution); Velázquez et al. 2010 (distribution); EsquivelMattos \& Peris 2011 (abundance, distribution, habitat); Madroño-Nieto 2011 (ethnology); Chachugi 2013 (ethnology); Smith et al. 2016 (abundance, distribution, habitat, status); Smith et al. 2017 (guide, identification); Lesterhuis et al. 2018 (guide, identification); Esquivel et al. 2019 (conservation, distribution); EsquivelMattos et al. 2019 (abundance, distribution, status); Sánchez et al. 2019 (ethnology).

Local names: Cuervo real ("royal vulture"), Cuervo blanco ("white vulture") (SPA); Yryvu ruvicha ("chief of the vultures") (GUA); Briku (ACHE); Chugupeja (TOTO); Ninionigi guopoba (MBYA).

Distribution: Typically a forest vulture that occurs at low density across most of the country, except for the extreme southwestern corner of the Oriental region (an area dominated by grasslands and swamps). Most frequent in the Chaco and north of $25^{\circ} \mathrm{S}$ in the Oriental region where it is associated with Atlantic Forests and forested areas of the Cerrado region. It shows no particular preference for humid or dry habitats, being present in both the most humid forests of the Oriental region and the most xeric areas of the Chaco region. The species is considered Near Threatened at the national level due to the continued loss of its forested habitat.

Taxonomy: This is Azara's No. 1 (1802) Iriburubichá.

Cultural value: Accounts of the cultural importance of this species to the Aché people are provided by Chachugi (2013) and to the Ayoreo Totobiegosode by Sánchez et al. (2019). The use of the feathers of this species are traditionally restricted to leaders amongst the Ayoreo Totobiegosode, (Sánchez et al. 2019) as these birds were considered to be the reincarnation of murdered ancestors (Bórmida \& Califano 2003). 
Azara (1802) notes that this species can be easily killed by placing a carcass in the forest and waiting nearby. Azara (1802) stated that the name of "chief of the vultures" is because of the respect shown by other vulture species at the carcass and not because of the size, echoing the sentiments of Sánchez Labrador (in Castex 1968) who went so far as to suggest that humans could learn something from the reverence shown to them by other vultures. Bertoni (1900) attributed the name to both size and respect, and added that other vulture species move away from the carcass upon their arrival. However, whilst other vultures are certainly subordinate at a carcass, the presence of a King Vulture does not make them retreat.

Observations: This species has been photographed feeding on a roadkill Red Tegu Salvator rufescens (Teiidae) in Alto Paraguay department (Paul Smith), and filmed feeding on a stillborn calf in Itapúa department (Hans Hostettler).

Specimens: Paraguayan specimens in FMNH, RBINS, UMMZ, USNM. See Andean Condor (in possible species).

\section{Black Vulture Coragyps atratus (Bechstein, 1793) (Figure 2).}

Vultur atratus Bechstein, 1793: p.655.

Cathartes foetens Hartlaub 1847 (checklist).

Cathartes atratus Berlepsch 1887 (checklist). Dalgleish 1889 (abundance, breeding, distribution); Kerr 1892 (abundance, distribution); Sclater 1897 (distribution); Bertoni 1900 (ecology); Bertoni 1901 (checklist).

Catharista urubu Ihering 1904 (checklist)

Catharista atratus brasiliensis Bertoni 1914a (checklist, distribution); Bertoni 1922 (distribution).

Coragyps urubu foetens Wetmore 1926 (distribution, taxonomy).
Coragyps atratus brasiliensis Bertoni 1930 (distribution); Vallotton \& Smith In press (specimens, taxonomy).

C.[oragyps] urubu foetens Bertoni 1930 (distribution).

Coragyps attratus foetens Bertoni 1939 (checklist, distribution).

Coragyps atratus foetens Laubmann 1939 (abundance, checklist, distribution); Podtiaguin 1941 (checklist); Podtiaguin 1944 (distribution); Pereyra 1945 (checklist); Willim 1947 (distribution); Schade \& Masi Pallarés 1967 (abundance, description); Contreras 1989 (distribution); Contreras et al. 1989 (distribution); Contreras et al. 1990 (checklist); Perez Villamayor \& Colmán 1995a (distribution); Masi Pallarés 2011 (ecology).

C.[oragyps] a.[tratus] brasiliensis Short 1975 (behaviour, distribution, habitat).

C.[oragyps] atratus Hayes \& Granizo Tamayo 1992 (density).

Coragyps atratus Short 1975 (behaviour, distribution, habitat); Escobar \& de Salomón 1983 (distribution); Kleefisch 1983 (distribution); López 1985 (distribution); Peris et al. 1987 (abundance, distribution); Hayes \& Areco de Medina 1988 (abundance, diet, distribution, flock size, habitat); Contreras \& González-Romero 1988 (distribution); Ritterbusch 1988 (distribution); Storer 1989 (mass); Hayes et al. 1991 (abundance, checklist); Neris \& Colman 1991 (abundance, distribution); Pérez Villamayor \& Colmán Jara 1995b (distribution); Hayes 1995 (abundance, biogeography, distribution); Hayes \& Scharf 1995a (abundance, distribution); Hayes \& Scharf 1995b (abundance, distribution); Amarilla \& Etcheverry 1996 (specimen); Lowen et al. 1996 (conservation, distribution); Madroño-Nieto et al. 1997a (distribution); Madroño-Nieto et al. 1997b (distribution, habitat); Robbins et al. 1999 (abundance, status, 
habitat); Kostadinova et al. 2002 (parasitology); Morales et al. 2002 (guide, identification); Mazar Barnett \& Madroño-Nieto 2003 (abundance, guide, identification); Zyskowski et al. 2003 (distribution); Clay et al. 2004 (guide, identification); Guyra Paraguay 2004 (abundance, distribution, habitat, status); Guyra Paraguay 2005 (abundance, distribution, habitat, status); Smith et al. 2005a (distribution); Smith et al. 2005b (distribution, status); Tierno de Figueroa \& Padial 2005 (abundance, distribution); Elsam $2006 \quad$ (guide, identification); Narosky \& Yzurieta 2006 (guide, identification); Smith et al. 2006a (distribution); Smith et al. 2006b (distribution); de la Peña 2010 (breeding); Morales \& Cardoso 2010 (distribution); López 2010 (abundance, distribution); Esquivel-Mattos \& Peris 2011 (abundance, distribution, habitat); MadroñoNieto 2011 (ethnology); Perez Villamayor \& Colmán 2011 (abundance, distribution, habitat); Esquivel-Mattos \& Peris 2012 (mass); Chachugi 2013 (ethnology); del Castillo 2014 (distribution); Weiler et al. 2015 (distribution); Ortiz et al. 2016 (abundance, distribution); Smith et al. 2016 (abundance, distribution, habitat, status); Cardozo et al. 2017 (abundance, distribution, habitat); Foster \& Johnson 2017 (diet, distribution, mass, specimen); Hayes 2017 (abundance, distribution); Irala et al. 2017 (abundance, distribution, habitat); Smith et al. 2017 (guide, identification); Etchegaray et al. 2018 (abundance, distribution); Esquivel et al. 2019 (conservation, distribution); EsquivelMattos et al. 2019 (abundance, distribution, status); Sánchez et al. 2019 (ethnology); ZárateBetzel et al. 2019 (distribution, habitat); Caballero-Gini et al. 2020 (distribution, habitat); Ericson \& Sosa 2020 (abundance, mass, specimens); Smith 2020 (guide).
Local names: Cuervo negro ("black vulture") (SPA); Yryvu hû ("black vulture") (GUA); Taydjã (ACHE); Coboto (TOTO).

Distribution: This species is abundant throughout Paraguay in all habitats and ecoregions.

Taxonomy: Paraguay is within the range of $C$. $a$. foetens (Lichtenstein, 1818), a name based on Azara's No. 2 (1802) Iribú. Wetmore (1926) provides a discussion for subspecific limits, and proposes the use of the name C. urubu (Vieillot, 1807), having examined the original description, it is difficult to concur with his conclusions on the latter.

Cultural value: In traditional Ayoreo Totobiegosode culture the feathers of this species are not touched by anybody who has not killed a Jaguar, and never touched by women as it will make them sick (Sánchez et al. 2019). Longevity is often attributed to this species, and it is claimed that the species can easily live for more than 100 years (Masi Pallarés 2011). Bertoni (1900) states that "everybody respects" the species, but the fact that there is always somebody who shoots indiscriminately at them, indicated the necessity for a law protecting the species.

Bertoni (1900) relates an interesting tale of a man who raised two Black Vultures from chicks, and that these birds followed him "over 100 leagues" on a trip to Montevideo, Uruguay. On the return leg the vultures flew ahead of the travelers, thus informing his wife that her husband would be arriving soon! The same author notes that if the prey animal has a thick skin, the species limits itself to eating the eyes, tongue and the meat from any orifice, including the anus. Masi Pallarés (2011) also provides a rather strange account of the feeding of this species, stating that if the bird introduces its head into the anus of dead livestock it can frequently consume so much that its increase in body mass traps it inside until this additional weight is lost again with digestion, and the animal 
is able to free itself. This would seem unlikely to be a typical occurrence!

Observations: This species is commonly attracted to carcasses of livestock, so is generally more numerous in the Oriental region than other vultures, and large numbers gather at the abattoir in Carapeguá, Paraguarí department where discarded animal remains are discharged into an adjacent swamp. An apparently injured bird that was unable to fly was seen to climb over a fence using its bill and feet at Laguna Bombacha, Presidente Hayes department (Figure 2).

Specimens: Paraguayan specimens in CM, DMNS, FMNH, MHNG, MNHNP, MVZ, NRM, UMMZ, USNM, WFVZ, YPM.

\section{Turkey Vulture Cathartes aura (Linnaeus, 1758) (Figure 3).}

[Vultur] Aura Linnaeus, 1758: p.86.

C.[athartes] aura Hartlaub 1847 (checklist).

Cathartes aura Berlepsch 1887 (checklist);

Dalgleish 1889 (abundance, breeding, distribution); Kerr 1892 (abundance, distribution); Bertoni 1900 (ecology); Bertoni 1901 (checklist); Ihering 1904 (checklist); Bertoni 1914a (checklist, distribution); Bertoni 1930b; Short 1975 (behaviour, distribution, habitat); Kleefisch 1983 (distribution); López 1985 (distribution); Hayes \& Areco de Medina 1988 (abundance, diet, distribution, habitat); Storer 1989 (mass); Hayes et al. 1991 (abundance, checklist); Neris \& Colman 1991 (abundance, distribution); SchmedaHirschmann 1993 (ethnology); Brooks et al. 1993 (abundance, distribution); Hayes 1995 (abundance, biogeography, distribution); Pérez Villamayor \& Colmán Jara 1995b (distribution); Hayes \& Scharf 1995a (abundance, distribution); Amarilla \& Etcheverry 1996 (specimen); Lowen et al. 1996 (conservation, distribution); Madroño-Nieto et al. 1997a (distribution); Madroño-Nieto et al. 1997b (distribution, habitat); Robbins et al. 1999 (abundance, status, habitat); Morales et al. 2002 (guide, identification); Mazar Barnett \& Madroño-Nieto 2003 (abundance, guide, identification); Zyskowski et al. 2003 (distribution); Clay et al. 2004 (guide, identification); Guyra Paraguay 2004 (abundance, distribution, habitat, status); Guyra Paraguay 2005 (abundance, distribution, habitat, status); Tierno de Figueroa \& Padial 2005 (abundance, distribution); Elsam 2006 (guide, identification); Smith 2006 (behaviour); Smith et al. 2005a (distribution); Smith et al. 2005b (distribution, status); Narosky \& Yzurieta 2006 (guide, identification); Smith et al. 2006a (distribution); Smith et al. 2006b (distribution); de la Pena 2010 (breeding); Morales \& Cardoso 2010 (distribution); López 2010 (abundance, distribution); Esquivel-Mattos \& Peris 2011 (abundance, distribution, habitat); MadroñoNieto 2011 (ethnology); Masi Pallarés 2011 (ecology); Perez Villamayor \& Colmán 2011 (abundance, distribution, habitat); EsquivelMattos \& Peris 2012 (mass); Chachugi 2013 (ethnology); del Castillo 2014 (distribution); Weiler et al. 2015 (distribution); Ortiz et al. 2016 (abundance, distribution); Smith et al. 2016 (abundance, distribution, habitat, status); Cardozo et al. 2017 (distribution); Foster \& Johnson 2017 (diet, distribution); Hayes 2017 (abundance, distribution); Irala et al. 2017 (abundance, distribution, habitat); Smith et al. 2017 (guide, identification); Lesterhuis et al. 2018 (guide, identification); Esquivel et al. 2019 (conservation, distribution); Esquivel-Mattos et al. 2019 (abundance, distribution, status); Sánchez et al. 2019 (ethnology); Zárate-Betzel et al. 2019 (distribution, habitat); Smith 2020 (guide).

Cathartes aura ruficollis Wetmore 1926 (distribution, taxonomy); Bertoni 1939 (checklist, distribution); Laubmann 1939 
(abundance, distribution, specimen); Podtiaguin 1941 (checklist); Podtiaguin 1944 (distribution); Pereyra 1945 (checklist); Schade \& Masi Pallarés 1967 (abundance, description); Short 1975 (behaviour, distribution, habitat); Contreras et al. 1990 (checklist); Contreras et al. 1989 (distribution); Perez Villamayor \& Colmán 1995a (distribution); Ericson \& Sosa 2020 (abundance, mass, specimens); Vallotton $\&$ Smith In press (specimens).

Cathartes aura jota Contreras 1989 (distribution); Contreras et al. 1990 (checklist).

Local names: Cuervo cabeza roja ("red-headed vulture") (SPA); Urubu capini, Yryvu akâ birâi ("bald-headed vulture") (GUA); Eapotoi (TOTO); Chiwura (ACHE); Napirai (MBYA)

Distribution: Fairly common in most habitats, across Paraguay though typically less common than Black Vulture over most of eastern Paraguay.

Taxonomy: Paraguay is within the range of $C$. $a$. ruficollis Spix, 1824. Wetmore (1926) provided a discussion of subspecies. This is Azara's No. 3 (1802) Acabiráy.

Cultural value: Prefers carcasses of native wildlife, though the local belief that the species never feeds on domestic animals is open to question (Hiraldo et al. 1991). Bertoni (1900) noted that this species abounds elsewhere, but is scarce in Paraguay, attributing this rarity to the fact that the species nests on the ground in October, and that the burning of the fields undoubtedly attributes to their lack of abundance. Bertoni worked in the dense forests of the Alto Paraná region where the species is naturally scarce. Burning practices in Paraguay were no different to those in neighbouring countries and though this undoubtedly destroys many nests, it is an unlikely explanation for their lack of abundance. Indeed, Sánchez Labrador (in Castex 1968) described this species as "abounding" in Paraguay.

Observations: We have observed this species feeding on roadkill of the following mammal species in the Paraguayan Chaco: Crab-eating Fox Cerdocyon thous, Pampas Fox Lycalopex gymnocercus, Crab-eating Raccoon Procyon cancrivorus (Fig. 3) and Southern Tamandua Tamandua tetradactyla. A heavily leucistic individual showing extensive white feathering on the breast and wings was photographed by Edgar Romero at Tetãvore, Boquerón department on 9 May 2020 (eBird).

Specimens: Paraguayan specimens in CM, DMNS, FMNH, MCZ, MHNG, MNHNP, RBINS, NRM, UMMZ, USNM, WFVZ, ZSM.

Lesser Yellow-headed Vulture Cathartes burrovianus Cassin, 1845 (Figure 4).

C.[athartes] Burrovianus Cassin, 1845: p.212.

Cathartes aura Grant 1911 (abundance, behaviour, specimen).

Cathartes urubutinga Bertoni 1914a (checklist, distribution); Bertoni 1939 (checklist, distribution); Laubmann 1939 (checklist, distribution, specimen); Podtiaguin 1944 (distribution); Schade \& Masi Pallarés 1967 (abundance, description, diet).

Cathartes urubitinga Wetmore 1926 (behaviour, distribution, identification); Willim 1947 (distribution); Steinbacher 1962 (moult, specimens, taxonomy).

C.[athartes] burrovianus López 1985 (distribution); Brooks et al. 1993 (abundance, distribution, identification).

Cathartes burrovianus urubutinga Peris et al. 1987 (abundance, distribution); Ericson \& Sosa 2020 (abundance, mass, specimens).

Cathartes burrovianus urubitinga Contreras et al. 1990 (checklist).

Cathartes burrovianus Short 1975 (distribution, habitat); López 1986 (abundance, distribution); Hayes \& Areco de Medina 1988 (abundance, diet, distribution, habitat); Storer 1989 (mass); Hayes et al. 1991 (abundance, checklist); Hayes 1995 (abundance, 
biogeography, distribution); Pérez Villamayor \& Colmán Jara 1995b (distribution); Lowen et al. 1996 (conservation, distribution); MadroñoNieto et al. 1997a (distribution); Mazar Barnett \& Madroño-Nieto 2003 (abundance, guide, identification); Zyskowski et al. 2003 (distribution); Guyra Paraguay 2004 (abundance, distribution, habitat, status); Guyra Paraguay 2005 (abundance, distribution, habitat, status); Smith 2005b (distribution, status); Tierno de Figueroa \& Padial 2005 (abundance, distribution); Elsam 2006 (guide, identification); Narosky \& Yzurieta 2006 (guide, identification); Smith 2006a; de la Pena 2010 (breeding); López 2010 (abundance, distribution); Esquivel-Mattos \& Peris 2011 (abundance, distribution, habitat); del Castillo 2014 (distribution); Smith et al. 2016 (abundance, distribution, habitat, status); Smith et al. 2017 (guide, identification); Esquivel et al. 2019 (conservation, distribution); EsquivelMattos et al. 2019 (abundance, distribution, status); Smith 2020 (guide).

Local names: Cuervo cabeza amarilla ("yellowheaded vulture") (SPA); Yryvu akâ sa'yju ("yellow-headed vulture") (GUA); Chivyra (ACHE); Nigopoba (MBYA).

Distribution: Common throughout the country in all open ecoregions, where it is associated with wet grassland and marshy habitats. Generally, flies lower than Turkey Vulture, with which it occurs sympatrically and syntopically, though it usually outnumbers that species in its preferred habitat.

Taxonomy: Paraguay is within the range of $C . b$. urubutinga Pelzeln, 1861, though subspecies are defined based on wing length and the variation is perhaps clinal (Ferguson-Lees \& Christie 2001). Wetmore (1926) provides a discussion on the use of this name. This is a sister species of Greater Yellow-headed Vulture (Johnson et al. 2016) and the two were not recognised as specifically distinct until Wetmore (1964) demonstrated its validity.
Until that point the combined taxon was commonly known as $C$. urubutinga Pelzeln, 1861 (Bertoni 1914a, 1939, Laubmann 1939, Willim 1947, Steinbacher 1962, Schade \& Masi Pallarés 1967), but C. burrovianus has priority (Wetmore 1950). Cultural value: The subspecific name urubutinga comes from the Tupi-Guaraní language meaning urubu "vulture" tinga "with white patches".

Observations: The species was mentioned by Sánchez Labrador in an (at the time) unpublished manuscript dated 1767. It was then remarkably overlooked by early researchers, perhaps because of its similarity to the Turkey Vulture, until Grant (1911), who listed the species as Cathartes aura from a specimen collected at Tayra, Neembucú department. The description of the head colour leaves no doubt that it was this species (Laubmann 1939). Schade \& Masi Pallarés (1967) affirm incorrectly that the species "does not mix with other vultures" and feeds "exclusively" on remains of small reptiles and batrachians. The diet is considerably wider (Di Giacomo 2005).

Specimens: Paraguayan specimens in CUMV, FMNH, NHM, NRM, RBINS, SMF, UMMZ, WFVZ, YPM, ZFMK, ZSM.

\section{Rejected species}

Andean Condor Vultur gryphus Linnaeus, 1758, was accepted onto the Paraguay list by Hayes (1995) and Guyra Paraguay (2004), but the existing documentation of the species in Paraguay is dubious. Podtiaguin (1944) provided the first report with a bird captured at Bahía de Asunción, Central department on 18 September 1943, but the author expressed doubts as to whether the bird may have been of captive origin. It is also unclear whether Podtiaguin actually saw the specimen (his text being notably briefer and lacking in details than those of other species) and some of the other claims in this publication also stretch the boundaries of credibility (Smith 2016b). The only other report is also unconfirmed, a specimen said to 
be captured by soldiers in the Paraguayan Chaco at General Eugenio A. Garay, Boquerón department (close to the Bolivian border) following a storm in August 1987 (Contreras 1989, Contreras et al. 1993). Supposedly the bird was photographed and then released, but the photograph can no longer be traced and it is unclear whether the authors saw the photo. Though this species does occasionally descend to the Chaco lowlands of Bolivia in winter (Kratter et al. 1993, Herzog et al. 2017), and is known to wander, we consider that documentation is required for acceptance. It is worthy of note that all verified reports of claimed condors in Paraguay in recent years have turned out to be King Vultures (ABC Noticias 2009). In the absence of verifiable proof it would seem best to consider this species of possible occurrence in the Paraguayan Chaco, and to omit it from the Paraguay list pending a documented record.

Greater Yellow-headed Vulture Cathartes melambrotus Wetmore, 1964, was cited by Contreras et al (1990) as of possible occurrence in Paraguay. However, the species has an Amazonian distribution and is unlikely to ever reach Paraguay (Ferguson-Lees \& Christie 2001). The supposition may have been influenced by older references which failed to distinguish the species from Lesser Yellow-headed Vulture (Wetmore 1964).

\section{Discussion}

Despite the abundance of New World vultures in Paraguay, their conspicuous behaviour and the key roles they play in healthy ecosystems, Cathartidae have been largely ignored by researchers in Paraguay. Data on population sizes and trends are non-existent, and even information on diet, breeding and movements is the product of occasional observation rather than structured study. Though none of the Paraguayan vultures are considered to be of conservation concern, research into potential threats to the species is desirable, especially to search for "hidden threats" that have been identified in other countries, such as deliberate poisoning (Plaza et al. 2019). We note that the sympatry of four vulture species reported for north-western Peru by Williams (2011) is repeated throughout much of Paraguay and all four may be seen together over large areas of the Paraguay River watershed (Wetmore 1926), although the species composition is distinct from that reported by Williams (2011). This should, theoretically, make Paraguay an interesting and rewarding place for vulture studies.

There remains widespread public misunderstanding of vulture behaviour in Paraguay, with local beliefs invariably reflecting negative attitudes towards them. However, this revulsion is not universal, and the unusual case of a pig farmer, Sr. Hans Stolle of Obligado, Itapúa was reported in the national media during 2016 (Sánchez 2016). He was given two vulture chicks which he raised alongside his livestock, and which later attracted large, apparently wild flocks of 500 or more birds (loosely described as his "pets"). Stolle notes that he had come to be known as "Señor Cuervo" (Mr Vulture) and that his neighbours take advantage of the waste disposal service provided by such large flocks of carrion eaters, throwing their dead animals to the vultures so that they can be devoured "without a nauseating smell in the area." The latter claim was subject to legal dispute during early 2020, when official complaints against the smell were filed with the Ministry of the Environment (Itapuanoticias.tv 2020).

It is hoped that the information provided here will be useful to vulture researchers, shedding some light on the available published literature and bringing some attention to existing overlooked references on the biology of these species in an often-overlooked country. 


\section{Acknowledgments}

Sergio Ríos provided helpful comments on an earlier version of this manuscript. The author is grateful to the Pronii programo of CONACyT Paraguay for support.

\section{References}

ABC Noticias. 2009. Pájaro rescatado en Peguaho es un Cóndor real joven. [https://www.abc.com.py/nacionales/pajaro-rescatado-en-peguaho-es-un-condor-real-joven16554.html] Accessed 22 ${ }^{\text {nd }}$ February 2021.

Amarilla, L. A. \& Etcheverry, N. 1996. Las aves del inventario biológico nacional. In: Romero Martínez, O. (Ed.). Colecciones de Flora y Fauna del Museo Nacional de Historia Natural del Paraguay, pp. 403467. MNHNP, Asunción, Paraguay.

Azara, F. de. 1802. Apuntamientos para la historia natural de los páxaros del Paraguay y Río de la Plata, Tomo 1. Imprenta de la Viuda de Barra, Madrid.

Azara, F. de. 1805a. Apuntamientos para la historia natural de los páxaros del Paraguay y Río de la Plata, Tomo 2. Imprenta de la Viuda de Barra, Madrid.

Azara, F. de. 1802. Apuntamientos para la historia natural de los páxaros del Paraguay y Río de la Plata, Tomo 3. Imprenta de la Viuda de Barra, Madrid.

Azara, F. de. 1809. Voyages dans l'Amérique Méridionale, 3. Oiseaux. Dentu, Paris.

Bechstein, J.M. 1793. Johann Latham's allgemeine Uberlicht der Vogel mit gemahlten zupfern aus dem Englischen uberfest. Ersten band zweiter theil. Weigel und Schneider, Nurnberg.

Bent, A.C. 1937. Life histories of North American birds of prey part 1: Order Falconiformes. Bulletin of the United States National Museum 167: 1-409.

Berlepsch, H. von. 1887. Appendix. Systematisches verzeichniss in der Republik Paraguay bisher beobachteten vogelarten. Journal für Ornithologie 35: 113-134.

Bertoni, A. de W. 1900. Catálogo descriptivo de las aves útiles del Paraguay. Revista de Agronomía y Ciencias Aplicadas, Asunción 2: 55-79.

Bertoni, A. de W. 1901. Aves nuevas del Paraguay. Continuación a Azara. Anales Científicos Paraguayos 1: 1-216.

Bertoni, A. de W. 1914a. Fauna Paraguaya. Catálogos sistemáticos de los vertebrados del Paraguay. M. Brossa, Asunción, Paraguay.

Bertoni, A. de W. 1914b. Los buitres y el carbunclo. Agronomía 5: 423-424.

Bertoni, A. de W. 1922. Aves observadas en el Parque y Museo Municipal de Asunción ex "Quinta Caballero" 1920-1921. Revista de la Sociedad Científica del Paraguay 1(3): 40-42.

Bertoni, A. de W. 1930. Anexo; Aves observadas por el Dr. A. Barbero Paraje Santa Jacinta en el Confuso (Chaco); Especies que no figuran en la colección de Posner. Revista de la Sociedad Científica del Paraguay 2(6): 257-258. 
Bertoni, A. de W. 1939. Catálogos sistemáticos de los vertebrados del Paraguay. Revista de la Sociedad Científica del Paraguay 4: 3-60.

Blake, E.R. 1977. Manual of Neotropical birds volume 1 Spheniscidae (Penguins) to Laridae (Gulls and allies). Chicago University Press, Chicago, USA.

Bock, W. J. 1994. History and nomenclature of avian family-group names. Bulletin of the American Museum of Natural History 222: 1-281.

Bórmida, M. \& Califano, M. 2003. Los indios Ayoreo del Chaco Boreal. Pp.7-224 In: Zanardini, J. (Ed.) Cultura del pueblo Ayoreo. Manual para docentes. Centro de Estudios Antropológicos de la Universidad Católica, Centro Social Indígena, Indianerhilfe in Paraguay \& V Biblioteca Paraguaya de Antropología, Asunción.

Brodkorb, P. 1964. Catalogue of fossil birds. Part 2 (Anseriformes through Galliformes). Bulletin of the Florida State Museum, Biological Series 8: 195-335.

Brooks, T.M., Barnes, R.B., Butchart, S.H., Clay, R.P., Esquivel, E.Z., Etcheverry, N.I., Lowen, J.C. \& Vincent, J.P. 1993. Bird surveys and conservation in the Paraguayan Atlantic Forest. BirdLife International Study Report No. 57. BirdLife International, Cambridge, UK.

Caballero-Gini, A., Bueno Villafañe, D., Laino, R. \& Musalem, K. 2020. Diversity of mammals and birds recorded with camera-traps in the Paraguayan Humid Chaco. Boletín del Museo Nacional de Historia Natural del Paraguay 24: 5-14.

Cadogan, L. 1959-1992. Ayvu rapyta. Textos míticos de los mbyá-guaraní del Guairá, Asunción: Fundación "León Cadogan"/CEADUC/ CEPAG.

Cardozo, R., Álvarez Gutierrez, A.A. \& Amarilla, L.A. 2017. Avifauna del campus de la Universidad Nacional de Asunción (San Lorenzo, Paraguay): Un mosaico de ambientes en el centro urbano. Boletín del Museo Nacional de Historia Natural del Paraguay 21: 48-58.

Cassin, J. 1845. Description of a new vulture in the Museum of the Academy of Natural Sciences of Philadelphia. Proceedings of the Academy of Natural Sciences, Philadelphia 2: 212.

Castex, M.N. (Ed.) 1968. Sánchez Labrador: Peces y aves del Paraguay. Natural ilustrado. Compañía General Fabril S. A., Buenos Aires.

Chachugi, R. 2013. Las aves y el conocimiento tradicional Aché. Fundación Moises Bertoni, Asunción.

Clay, R. P., Morales, C., Esquivel, A. \& Klavins, J. 2004. 102 aves comunes del Paraguay. Guyra Paraguay, Asunción.

Contreras, J.R. 1989. La avifauna de la Estancia Coë Pyahú y sus cercanías, Nueva Asunción, República del Paraguay. Notúlas Faunísticas 17: 1-6.

Contreras, J.R., Contreras, A.O. \& Escobar Argaña, J. 1993. Comentarios acerca de algunas especies de aves nuevas o poco conocidas para el Paraguay. Notúlas Faunísticas 43: 1-7.

Contreras J.R. \& González-Romero, N. 1988. Una avifauna intraurbana en la ciudad de Asunción, departamento Central, República del Paraguay. In J.R. Contreras (ed.) Ornitologia: ArgentinaParaguay 1988. Corrientes. Pp.30-34 
Contreras, J.R., González-Romero, N., Peris Álvarez, S.J., Contreras, A.O. \& Acevedo, C. 1989. Contribución al conocimiento de la avifauna del Lago Ypoá y regiones adyacentes del dpto. de Paraguarí (Paraguay). Informes Científicos 6: 35-53.

Contreras, J.R., González-Romero, N. \& Berry, L.M. 1990. Lista preliminar de la avifauna de la República del Paraguay. Cuadernos Técnicos Félix de Azara 2: 1-42.

Dalgleish, J.J. 1889. Notes on a collection of birds and eggs from the Republic of Paraguay. Proceedings of the Royal Physical Society of Edinburgh 10: 73-88.

De la Peña, M. 2010.Guía de los nidos de aves del Paraguay. Guyra Paraguay, Asunción.

del Castillo, H. 2014. La lista de las aves de Asunción. Paraquaria Natural 2(1): 29-42.

Di Giacomo, A.G. 2005. Aves de la Reserva El Bagual. In: Di Giacomo, A.G. \& Krapovickas, S. (Eds.). Historia natural y paisaje de la Reserva El Bagual, provincia de Formosa, Argentina. Temas de Naturaleza y Conservación 4, pp. 201-465. Aves Argentinas, Buenos Aires, Argentina.

Dobrizhoffer, M. 1784. Historia de Abiponibus Equestri, Bellicosaque Paraguariae Natione. Josephi Nob. De Kurzbek. Viennae, Austria.

Elsam, R. 2006. Guía de aves del chaco húmedo. Guyra Paraguay, Asunción.

Ericson, P.G.P. \& Sosa, W. 2020. Birds collected and captured during the PROVEPA ornithological fieldwork in Paraguay 1993-1999. Reports from the Swedish Museum of Natural History 2020 (1): 1209.

Escobar M.E. \& de Salomón, M.J. 1983. Contribución al conocimiento de algunas especies de aves que habiten el Campus Universitario de Universidad Nacional de Asunción-Paraguay. I Symposio de Ornitología Neotropical, (IX CLAZ Peru), October 1983: 23-25.

Esquivel, A., Zarza, R., Tiffer-Sotomayor, R., Díaz, A., Pérez, D. \& Velázquez, M. 2019. Conservation status and challenges of the Atlantic Forest birds of Paraguay. Diversity 11 (247): doi: $10.3390 / \mathrm{d} 11120247$

Esquivel-Mattos, A. \& Peris, S.J. 2011. Aves de San Rafael. Universidad de Salamanca/ Asociación Pro Cosara, Asunción.

Esquivel-Mattos, A. \& Peris, S.J. 2012. Estructura y organización de una comunidad de aves del Bosque Atlántico de San Rafael, Paraguay. Ornitología Neotropical 23: 569-584.

Esquivel-Mattos, A., Tiffer-Sotomayor, R., Díaz, A., Centrón, S., Bartina, L., Ruíz, R., Clay, R.P., del Castillo, H. \& Yanosky, A. 2019. The avifauna of Ypetî Nature Reserve, and its implication for the consolidation of the Atlantic Forest Corridor in Paraguay. Wilson Journal of Ornithology 131: 35-42.

Etchegaray, A.M., Esquivel-Mattos, A. \& Weiler, A. 2018. Estructura de las comunidades de aves de cuatro áreas verdes de la ciudad de Asunción, Paraguay. Revista de Ciencias Ambientales 52: 184207.

Ferguson-Lees, J. \& Christie, D.A. 2001. Raptors of the world. Houghton Mifflin, Boston.

Freile, J.F., Greeney, H.F. \& Bonaccorso, E. 2014. Current Neotropical ornithology: Research progress 1996-2011. Condor Ornithological Applications 116: 84-96.

Foster, M.S. \& Johnson, N.K. 2017. The annual cycle and natural history of a subtropical Atlantic Forest avifauna in Paraguay. Smithsonian Contributions to Zoology 648: 1-83. 
Glading, B. \& Glading, C.H. 1970. An instance of a captive Turkey Vulture killing prey. Condor 72: 244245.

Grant, C.H.B. 1911. List of birds collected in Argentina, Paraguay, Bolivia and southern Brazil with field notes. Ibis (9)5: 317-350.

Guyra Paraguay. 2004. Lista comentada de las aves de Paraguay / Annotated checklist of the birds of Paraguay. Guyra Paraguay, Asunción, Paraguay.

Guyra Paraguay. 2005. Atlas de las aves de Paraguay. Guyra Paraguay, Asunción, Paraguay.

Hartlaub, C.J.G. 1847. Systematischer index zu Don Félix du Azara's Apuntamientos para la Historia Natural de los Páxaros del Paraguay y Río de la Plata. Schünemann, Bremen, Germany.

Hayes, F.E. 1995. Status, distribution and biogeography of the birds of Paraguay. American Birding Assocation, Monographs in Field Ornithology 1, Albany, New York, USA.

Hayes, F.E. 2017. The avifauna of Serranía de Tobatí, Departamento Cordillera, Paraguay. Paraquaria Natural 5(1): 18-23.

Hayes, F.E. \& Areco de Medina, F.E. 1988. Notes on the ecology of the avifauna of Chore, department of San Pedro, Paraguay. El Hornero 13: 59-70.

Hayes, F.E. \& Granizo Tamayo, T. 1992. Bird densities along three tributaries of the Paraná River in eastern Paraguay. El Hornero 13: 254-256.

Hayes F.E \& Scharf, P.A.. 1995a. The birds of PN Cerro Corá, Paraguay. Cotinga 4: 20-24.

Hayes F.E \& Scharf, P.A.. 1995b. The birds of PN Ybycuí, Paraguay. Cotinga 4: 14-19.

Hayes, F.E., Scharf, P.A. \& Loftin, H. 1991. A birders field checklist of the birds of Paraguay. Russ's Natural History Books, Lake Helen, Florida.

Hiraldo, F., Delibes, M. \& Donazar, J.A. 1991. Comparison of diets in Turkey Vultures in three regions of northern Mexico. Journal of Field Ornithology 61: 319-324.

Ihering, H. von. 1904. As aves do Paraguay em comparação con as de São Paulo. Revista do Museu Paulista 6: 310-344.

Irala, R., Martin, A. \& Velázquez, M.C. 2017. Riqueza de aves en la Compañia Naranjaity, distrito de Sapucái, departamento Paraguarí, durante el período de Marzo a Diciembre de 2016. Boletín del Museo Nacional de Historia Natural del Paraguay 21: 35-47.

Itapuanoticias.tv. 2020. Denuncian a dueño de finca por contaminación ambiental en Obligado. [https://itapuanoticias.tv/denuncian-a-dueno-de-finca-por-contaminacion-ambiental-en-obligado/] Accessed $22^{\text {nd }}$ February 2021.

Johnson, J.A., Brown, J.W., Fuchs, J. \& Mindell, D.P. 2016. Multi-locus phylogenetic inference among New World Vultures (Aves: Cathartidae). Molecular Phylogenetics and Evolution 105: 193-199.

Kerr, J.G. 1892. On the avifauna of the Lower Pilcomayo. Ibis 6(4): 120-152.

Kleefisch Jr., T. 1983. Vogelbeobachtungen in Paraguay. Trochilus 4: 105-113.

Kostadinova, A., Vaucher, C. \& Gibson, D.I. 2002. Redescriptions of two echinostomes from birds in Paraguay, with comments on Drepanocephalus Dietz, 1909 and Paryphostomum Dietz, 1909 (Digenea: Echinostomatidae). Systematic Parasitology 53: 147-158. 
Kratter, A.W., Sillett, T.S., Chesser, T., O'Neill, J.P., Parker III, T.A. \& Castillo, A. 1993. Avifauna of a Chaco locality in Bolivia. Wilson Bulletin 105: 114-141.

Lambertucci, S.A., Margalida, A., Speziale, K.L., Amar, A., Ballejo, F., Bildstein, K.L., Blanco, G., Botha, A.J., Bowden, C.G.R., Cortés-Avizanda, A., Duriez, O., Green, R.E., Hiraldo, F., Ogada, D., Plaza, P., Sánchez-Zapata, J.A., Santangeli, A., Selva, N., Spiegel, O. \& Donázar, J.A. 2021. Presumed killers? Vultures, stakeholders, misperceptions and fake news. Conservation Science and Practice 3: e415.

Laubmann, A. 1939. Die vögel von Paraguay Erster Band. Strecker und Schröder, Stuttgart.

Lesterhuis, A.J., Bueno Villafañe, D., Cabral Beconi, H.E. \& Rojas Bonzi, V.B. 2018. Guía de las aves del Chaco Seco Paraguayo. Guyra Paraguay, Asunción.

Lichtenstein, M.H.C. 1818. Verzeichniss von ausgestopften Säugethieren und Vögeln, welche am 12ten October 1818 u. folg. Tage im zoologischen Museum der Königl. Universität zu Berlin durch den Königl. Auctionscommissarius Bratring dem Meistbietenden öffentlich verkauft werden sollen. Berlin.

Linnaeus, C. 1758. Systema naturae per regna tria naturae secundum classes, ordines, genera, species cum characteribus differentiis synonymis locis 10th Ed. Guilelmi Engelmann, Lipsiae.

López, N.E. 1985. Avifauna del departamento de Alto Paraguay. El Volante Migratorio 4: 9-13.

López, N.E. 1986. Paraguay. In: Scott, D.A. \& Carbonell, M. (Eds.). A directory of Neotropical wetlands, pp. 200-208. IUCN and IWRB, Cambridge and Slimbridge.

López, N.E. 2010. Avifauna de la cuenca del Río Pilcomayo, lado Paraguayo. Revista de la Sociedad Cientifica del Paraguay 15: 153-169.

Lovell, H.B. 1952. Black Vulture depredations at Kentucky woodlands. Auk 64: 48-49.

Lowen, J.C., Bartrina, L., Clay, R.P. \& Tobias, J.A. 1996. Biological surveys and conservation priorities in eastern Paraguay. CSB Conservation Publications, Cambridge, UK.

Lowney, M.S. 1999. Damage by Black and Turkey Vultures in Virginia, 1990-1996. Wildlife Society Bulletin 27: 715-719.

Madroño-Nieto, A., Clay, R.P., Robbins, M.B., Rice, N.H., Faucett, R.C. \& Lowen, J.C. 1997a. An avifaunal survey of the vanishing interior Atlantic forest of San Rafael National Park, Departments Itapúa/Caazapá, Paraguay. Cotinga 7: 45-53.

Madroño-Nieto, A. 2011. Conocimiento tradicional de los indígenas Aché de Mbaracayú sobre las aves del Bosque Atlántico del Paraguay. Suplemento Antropológico 46: 317-398.

Madroño-Nieto, A., Robbins, M.B. \& Zykowski, K. 1997b. Contribución al conocimiento ornitológico del Bosque Atlántico Interior del Paraguay: PN Caaguazú, Caazapá. Cotinga 7: 54-60.

Masi Pallarés, R. 2011. Vertebrados del Paraguay. Descripción y hábitos con las denominaciones en Guaraní. 2nd Ed. Servilibro, Asunción.

Mazar Barnett, J. \& Madroño-Nieto, A. 2003. Aves de la Reserva Natural del Bosque Mbaracayú: Guía para la identificación de 200 especies. Guyra Paraguay/Fundación Moises Bertoni, Asunción, Paraguay.

Melia, B. 2006. Mitología Guaraní. p.177-210. In: Ortíz Rescaniere, A. (Ed.) Mitologías Ameríndias. Editorial Trotta, Madrid. 
Melo, M.A., Batistelli, A.F., Guillermo-Ferreira, R. \& Piratelli, A.J. 2008. "Wanted dead or alive": Black Vultures (Coragyps atratus) feeding on a live Capybara (Hydrochoerus hydrochaeris). Ornitología Neotropical 29: 91-93.

Morales, C. \& Cardoso, R.M. 2010. Evaluación de la importancia del Bañado Tacumbú (Asunción Paraguay) para la conservación de las aves acuáticas. Reportes Científicos de la FaCEN 1(1): 20-29.

Morales, C., Esquivel, A. \& Klavins, J. 2002. 101 aves comunes del Paraguay. Guyra Paraguay, Asunción.

Mueller, H.C. \& Berger, D.D. 1967. Turkey Vultures attack living prey. Auk 94: 430-431.

Narosky, T. \& Yzurieta, D. 2006. Guía para la identificación de las aves de Paraguay. Vazquez Mazzini, Buenos Aires.

Neris, N. \& Colman, F. 1991. Observaciones de aves en los alrededores de Colonia Neuland, departamento Boquerón, Paraguay. Boletín del Museo Nacional de Historia Natural del Paraguay 10: 1-10.

Olson, S. 1995. Book review: History and Nomenclature of Avian Family-Group Names.- Bulletin of the American Museum of Natural History, volume 222. W. J. Bock. 1994. 281 pages. Auk 112: 539-546.

Ortíz, F., Núñez, K. \& Amarilla, L. 2016. Riqueza, composición y abundancia de aves del Campus Universitario de la Universidad Nacional de Asunción, San Lorenzo, Paraguay. Revista del Museo de La Plata 1: 11-20.

Pereyra, J.A. 1945. La obra ornitológica de Don Félix de Azara. Biblioteca Americana, Buenos Aires.

Pérez Villamayor, N. \& Colmán Jara, A. 1995a. Avifauna de Área Itaipú. Itaipú Binacional Biota 2: 2555.

Pérez Villamayor, N. \& Colmán Jara, A. 1995b. Avifauna de las áreas protegidas de Itaipú I: Aves del Refugio Biológico Mbaracayú, Salto del Guairá, Paraguay. Itaipú Binacional Biota 4: 1-24.

Pérez Villamayor, N. \& Colmán Jara, A. 2011. Avifauna de las áreas protegidas de Itaipú 2: Aves del Refugio Biológico Tatí Yupí. Itaipú Binacional Biota 14: 1-45.

Peris, S., Cabello, L.A., Suárez, L. \& Peco, B. 1987. Las aves del bajo Chaco: Evaluación preliminar. Informes Científicos del Instituto de Ciencias Básicas, Asunción 5: 27-33.

Plaza, P.I., Martínez-López, E. \& Lambertucci, S.A. 2019. The perfect threat: Pesticides and vultures. Science of the Total Environment 687: 1207-1218.

Podtiaguin, B. 1941. Catálogo sistemático de las aves del Paraguay. Aumentado por las contribuciones al conocimiento de la ornitología paraguaya. Revista de la Sociedad Científica del Paraguay 5(5): 1-109.

Podtiaguin, B. 1944. Catálogo sistemático de las aves del Paraguay. Aumentado por las contribuciones al conocimiento de la ornitología paraguaya. Suplemento al catálogo. Revista de la Sociedad Científica del Paraguay 6(3): 7-120.

Ritterbusch, B. 1988. Estudio limnologico del Lago Ypacaraí. Revista de la Asociación de Ciencias Naturales del Litoral 19: 11-16.

Robbins M.B., Faucett, R.C. \& Rice, N.H. 1999. Avifauna of a Paraguayan cerrado locality: PN Serranía San Luis, Depto. Concepción. Wilson Bulletin 111: 216-228.

Sánchez, F. 2016. Poblador cría cerca de 500 cuervos como mascotas. ADN Digital https://www.adndigital.com.py/poblador-cria-cerca-de-500-cuervos-como-mascotas/ 
Sánchez, P., Bonzi, A. \& S. D. Ríos, S.D. 2019. Patrimonio natural y cultural Ayoreo Totobiegosode. Notas de etnozoología y etnopaisaje. OPIT/GAT, Asunción.

Sánchez Labrador, J. 1910. El Paraguay Católico. Homenaje de la Universidad Nacional de La Plata al XVII Congreso Internacional de los Americanistas en su reunión de Buenos Aires, en mayo 16 a 21 de 1910. Buenos Aires, Argentina.

Scavone, C. 2014. Los buitres del Paraguay. $A B C$ Color https://www.abc.com.py/edicionimpresa/opinion/los-buitres-del-paraguay-1278400.html

Schade, F. \& Masi Pallarés, R. 1967. Las aves del Paraguay 1a Parte. Revista Paraguaya de Microbiología 2: $72-85$.

Schmeda-Hirschmann, G. 1993. Magic and medicinal plants of the Ayoreos of the Chaco Boreal (Paraguay). Journal of Ethnopharmacology 39: 105-111.

Sclater, P.L. 1897. Extracts from a letter received from Mr. Graham Kerr, dated Villa Concepcion, Paraguay, Oct. 17th, 1896. Ibis 7(3): 257.

Sharpe, R.B. 1874. Catalogue of the Accipitres or diurnal birds of prey in the collection of the British Museum. British Museum of Natural History, London.

Short, L.L. 1975. A zoogeographical analysis of the South American chaco avifauna. Bulletin of the American Museum of Natural History 154: 163-352.

Smith, P. 2006. Interspecific aggression in nesting great kiskadees (Pitangus sulphuratus) in Paraguay. Boletín SAO 16: 67-70.

Smith, P. 2016b More comments and recommendations on Paraguayan "hypothetical" species: Rhea pennata (Rheidae), Buteogallus aequinoctialis (Accipitridae), Columbina passerina (Columbidae), Caprimulgus hirundinaceus (Caprimulgidae) and Atlapetes citrinellus (Emberizidae). Boletín Museo Nacional de Historia Natural del Paraguay 20: 53-56.

Smith, P. 2020. Guía para la identificación de aves de Asunción y su área metropolitana (AMA). PNUD, Asunción.

Smith, P., Betuel, A., Batjes, H., Centrón, S. \& del Castillo, H. 2006a. An avifaunal inventory of PN Teniente Agripino Enciso, Departamento Boquerón, northern Paraguay. FAUNA Paraguay Technical Publication 4: 1-8.

Smith, P., del Castillo, H., Bankovics, A., Hansen, L. \& Wainwright, B. 2006b. An avifaunal inventory of San Rafael "National Park", Departamento Itapúa, southern Paraguay. FAUNA Paraguay Technical Publication 3: 1-13.

Smith, P., del Castillo, H., Batjes, H., Betuel, A., Montiel, M., Nossent, R., Onley, D., Wainwright, B. \& Wechsler, S. 2005a. An avifaunal inventory of Hotel Tirol, departamento Itapúa, southern Paraguay. FAUNA Paraguay Technical Publication 1: 1-14.

Smith, P., del Castillo, H., Batjes, H., Montiel, M. \& Wainwright, B. 2005b. An avifaunal inventory of Laguna Blanca, Departamento San Pedro, northeastern Paraguay. FAUNA Paraguay Technical Publication 2: 1-16. 
Smith, P., del Castillo, H. \& Guest, K. 2016. Birds of Reserva Natural Laguna Blanca, departamento San Pedro, Paraguay and the imminent threats to their conservation. Revista Biodiversidad Neotropical 6: 55-67.

Smith, P., Güller, R.M. \& H. del Castillo, H. 2017. Guía de campo de las aves de San Rafael. Pro Cosara, Hohenau.

Steinbacher, J. 1962. Beiträge zur kenntnis der vögel von Paraguay. Abhandlungen Senckenbergischen Naturforschenden Gesellschaft 502: 1-106.

Storer, R.W. 1989. Notes on Paraguayan birds. Occasional Papers of the Museum of Zoology, University of Michigan 719: 1-21.

Tierno de Figueroa, J.M. \& Padial, J.M. 2005. Avifauna invernal en ambientes de Chaco y Pantanal en Bahía Negra, norte de Paraguay. El Hornero 20: 153-162.

Vallotton, L. \& Smith, P.. In press. Paraguayan birds in the collection of the Museum of Natural History, Geneva, Switzerland. Boletín del Museo Nacional de Historia Natural del Paraguay.

Velázquez, M.C., Ramírez Pinto, F. \& Rodríguez Montiel, L. 2010. Flora y fauna amenazada de la Reserva Natural Privada Tapytá. Fundación Moises Bertoni, Asunción.

Vieillot, L.P. 1807. Histoire naturelle des oiseaux de l'Amérique Septentrionale contenant un grand nombre d'espèces décrites ou figurées pour la première fois. Tome premier. Desray, Paris.

Weiler, A., Nuñez, K., Airaldi-Wood, K., Caballero-Gini, A., Bauer, F. \& Cardozo, R. 2015. Aves de la Reserva de Recursos Manejados Lago Ypacarai. Revista de la Sociedad Científica del Paraguay 20: 63-73.

Wetmore, A. 1926. Observations on the birds of Argentina, Paraguay, Uruguay and Chile. Bulletin of the United States National Museum 133: 1-448.

Wetmore, A. 1950. The identity of the American vulture described as Cathartes burrovianus by Cassin. Journal of the Washington Academy of Science 40: 415-417.

Wetmore, A. 1964. A revision of the American vultures of the genus Cathartes. Smithsonian Miscellaneous Collections 146 (6): 1-18.

Williams, R.S.R. 2011. Sympatric occurrence of four Cathartid vultures in the dry forests of north-western Peru. Vulture News 61: 31-32.

Willim, P. 1947. Contribuciones al conocimiento de las aves del Chaco Paraguayo. Revista de la Sociedad Científica del Paraguay 7(2): 1-4.

Zárate-Betzel, G.I., Weiler Gustafson, A., Núñez Goralewski, K.B., Esquivel Mattos, A., Amarilla Rodríguez, S.M. \& Pech-Canché, J.M. 2019. Cámaras trampa como método de muestreo para aves del Chaco Seco paraguayo: una comparación con los métodos auditivos y visuales. Revista de Biología Tropical 67: 1089-1102.

Zyskowski, K., Robbins, M.B., Townsend Peterson, A., Bostwick, K.S., Clay, R.P. \& Amarilla, L.A. 2003. Avifauna of the northern Paraguayan Chaco. Ornitologia Neotropical 14: 247-262. 